\title{
保全特性関数による鉄道走行路面状態の推移モデル

\author{
A MODEL FOR TRACK SURFACE CONDITION WITH USE OF \\ MAINTENANCE CHARACTERISTIC FUNCTIONS
}

\author{
家田 仁*·佐藤吉彦**・持永敬彦***
}

By Hitoshi IEDA, Yoshihiko SATO and Takahiko MOCHINAGA

\begin{abstract}
Railway tracks subside gradually with train passages and irregularities of track surface grow by degrees. These track irregularities must be systematically controlled, because they are liable to detract passengers' ride comfort and also trains' running safety. Now that rationalization of maintenance system is being required more and more, it has become important to estimate irregularity condition, to predict how much maintenance work should be done to hold the irregularity to a specific level, or to know what factors are related to these surfacing works.

In this study, a model adopting the Maintenance Characteristic Functions (Selected Condition Function in track maintenance and Restored Condition Function) that can simulate deterioration and repair process of surface condition was proposed for those purposes, and its applicability was verified using the data on Japanese National Railways system.
\end{abstract}

Keywords : track irregularity, maintenance characteristic functions

1.はじめに

線路は経験的構造物として，保全されることを前提と して構造や管理のシステムが構成されており, 列車荷重 により生じる不均等な沈下によって増大する走行路の幾 何学的不整（すなわち軌道狂い）は列車の走行安全や乗 客の乗心地に直接的な影響を及ぼすため, 軌道狂い状態 の管理は線路の保全の中でも重要な位置付けを占めてい

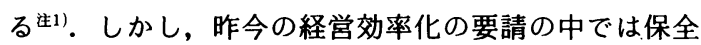
システムのより合理的な運営への期待も大きく, 管理指 標や基準値の設定方法や整正作業技術とともに，軌道状 態の予測や保全所要量の予測などの保全計画策定の技術 の深度化か強く期待されている. 本研究は,こうした要 請の中で実用的な軌道状態予測モデルとして, 保全の基

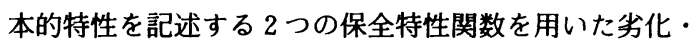
保全モデルを提案し, その適用性の検討を行ったもので ある.

* 正会員 工博 東京大学助教授 工学部土木工学科

（下113 文京区本郷 7-3-1）

**正会員 工博 (株) 日本線路技術, 碩問 ( ₹160 新宿区新宿 3-36-10)

*** 正会員 技術士（建設部門）（株）日本線路技術, 調查役 (同上)

\section{2. 従来の研究と本研究の目的}

軌道における走行路の幾何学的不整の進行とその保全 に関しては, 多くの研究が行われているが, それらは大 別して次の 3 種に分類することができる．第一は軌道沈 下の力学的性質に関する理論的および実験的な研究であ る.これらは, 列車荷重や軌道構造に応じてどのように 軌道が沈下していくか, つまり外部の条件と沈下量との 関係に主な関心が置かれた研究が多く，軌道構造の沈下 に対する強度の評価基準（軌道構造係数）の提案 ${ }^{1}$ や, 高周波振動の見地からの車両と軌道の相互作用に関する 研究致ば゙が行われている. 第二は，走行路の不整の管 理基準に関する研究である.これらは, 列車の走行安全 や乗客の乗心地確保という観点からの, 走行路の不整の 計測・評価法や管理基準の設定法等に関する理論解析を 中心とした研究(1)-5)である.これらに対して，第三の分 類として実際の軌道計測デー夕を統計的に解析した実証 的研究がある.これらは, 軌道狂いの確率分布に関する

注 1）䩔道狂いの管理は，基本的には軌道の上下変位，左右 変位, 左右レール面の高低差, 走行面のねじれ, 左右レールの 間隔の 5 要素について行われているが, 本研究ではその中でも 不整の進行が最も速く, 保全コストの大部分を占める上下方向 変位 (高低狂い) の問題を扱う. 
研究 ${ }^{6)}$, 走行路不整状態の進行速度の評価値として一定 長のロット内における最大絶対值の時間的変化率（軌道 狂い進み）をとり，これが外部の条件とどのような統計 的関係にあるかを検討した研究7), 軌道状態が均衡して いる状況のもとにおける軌道状態と軌道狂い進み，保全 実施率との統計的関係に関する研究8)などが行われてい る.

技術上の実用的要請としては, 第一, 第二のグループ に属するような基礎的研究のほかに，効率的な保全計画 策定に直接用いることのできる計画理論構築への期待が 大きい．そのような意味で第三のグループに属する研究 は走行路保全に関する多くの知見を計画者にもたらした が,これまでのところ軌道状態の劣化と保全を総合的か つ定式的にとらえたモデルが構築されていなかったこと もあり，本来必ずしも均衡しているとは限らない軌道状 態の推移を一般的に表現することができなかった。

さて，保全計画策定技術に関する実用上のニーズにつ いては次の 2 つに大別できる.

I. 対象をマクロにとらえて, 軌道構造, 状態管理水 準, 輸送条件などの政策変数の変化を長期的視野に 立って評価するためのもの.

II. 個別の対象について, 実用的時間スケールの中で, 軌道状態の推移状況や，特定の目標水準に移行する ために要求される保全量を定量的かつ精度高く予測 することを目的とするもの.

これらに対して, システム・ダイナミックスの手法を 用いた軌道状態のマクロな長期予測も試みられている ${ }^{9}$. これは I の目的に該当するものであり，各種要因の物理 的因果関係や定量的関数関係，モデルの適合性検証に課 題が残されている面があるが，マクロな定性的予測とい う目的からは 1 つの新しい試みである. 一方，IIの目的 については新幹線の軌道管理で一部武みられているが十 分な成果をあげているとはいいがたい。

保全を含めたシステムを定式的にとらえるうえでは， (1)状態指標の設定，(2)劣化特性の記述，(3)保全対象の決 定過程の記述，(4)保全実施による整正過程の記述，(5)状 態指標管理水準の設定,の各過程を明らかにしなければ ならないと考えられる. 本研究では, こうした各過程を 明示的にとらえつつ， II の実用的予測を目的として，軌 道状態の推移モデルを構築し，実データによりその各種 パラメーターの推定およびモデルの適用性の検討を行 う.

\section{3. 保全特性関数を用いた劣化・保全モデルの 構成}

\section{（1）状態指標の設定}

軌道面の幾何学的不整の状態を管理するには，当然の
ことながらその状態を表わす適当な指標を設定する必要 がある．軌道管理におけるこうした状態指標は，その使 用目的に応じて, 測定された軌道狂い值自身や統計的に

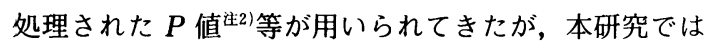
饮に述べる理由から延長 $20 \mathrm{~m}$ のロット内における高低 狂いの最大絶対値 $D$ をしかるべき延長の区間内で平均 した值 (平均最大値) $\bar{D}$ を状態指標としてとることとし た。

軌道狂いの整正は, 列車の走行安全性や乗客の乗心地 を確保するためのものである.この際, 問題となるのは まず軌道狂いの最大振幅であることから，区間最大值を 指標の基本におくことは目的に適合している．また，現 存する軌道狂いは $10 \mathrm{~m}$ 弦正矢量として測定されている ことに起因して $10 \sim 20 \mathrm{~m}$ 付近の波長が卓越し，基本 ロット長を $20 \mathrm{~m}$ 程度にとることにも妥当性がある.さ らに最大值 $D$ は，ガンベル分布に従って確率的に分布

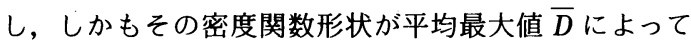
一意的に定められることが明らかにされているため ${ }^{10)}$, 平均最大値 $\bar{D}$ を指標にとって予測することにより，最 大值の確率分布までもが推定できることになる．このた め管理上多用される整備基準値の超過確率等に対しても 応用が容易となる。

また，劣化特性の評価には最大值 $D$ の時間的変化率 である軌道狂い進みを用いる方法がこれまで確立されて おり，本研究でも実データからの推定値としてこれを用 いるが，この点でも状態指標に平均最大値 $\bar{D}$ を用いる のは合理的である.

線路の管理の立場からみれば，各地点の個々の軌道狂 い値よりも相当延長の区間における軌道狂いの統計的特 性を予測することに意義が高く，この点でも平均最大值 $\bar{D}$ を用いることは目的にかなっている。

\section{（2）保全対象の選択特性}

いま，延長 $L$ の対象区間をとり，時期 $T_{S}$ と $T_{E}$ の間 での期間を $\Delta T$ として状態指標の推移を記述すること を考える. 以下では, 時期 $T_{S}$ を初期, 時期 $T_{E}$ を終期 とよぶ.この区間について, 状態指標である平均最大値 $\bar{D}$ が劣化していく状況と保全により整正される様子を 概念的に示したのが図一1である.この区間における期 間 $\Delta T$ の間における保全実施延長を $l$ とする. 保全率 $m=l / L$ が 1 より小さい場合には, 対象区間は

|一般区間：保全を行わない区間（非保全区間）

選択区間：保全を 1 回行う区間（保全区間） に区分することができる，さらに，一般的に保全率 $m$ が, $N$ を自然数として,

$N-1 \leqq m<N$

注 2） $P$ 值は軌道狂いの絶対値が一定の限度を超過する確率 として定義され, その限度值としては $3 \mathrm{~mm}$ が用いられてきた. 


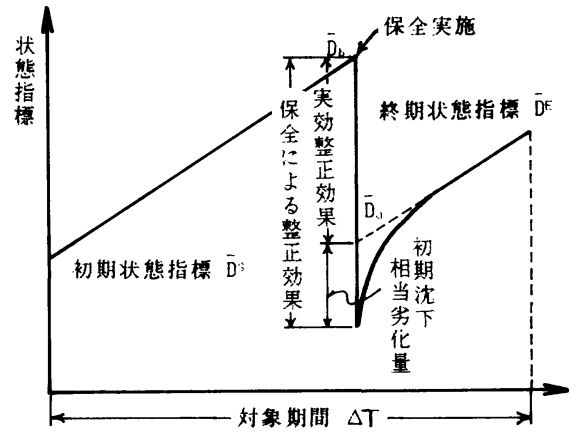

図一1状態指標推移の模式図

を満たす場合には，対象区間は，

一般区間：N-1 回保全を行う区間

選択区間 $: N$ 回保全を行う区間

に区分することができる祊3．このときそれぞれの区間 の延長 $L_{-}, L_{+}$は, 次のとおり算出される.

$L_{-}=N L-l=(N-m) \cdot L$

$L_{+}=l-(N-1) \cdot L=(m-N+1) \cdot L$

ここで, $m-N+1$ の値は, 重点的に保全される箇所と して選択された区間の全体に占める比率を表わすため, ここでは特に選択保全率とよぶ. いま, 対象区間全体の 初期状態指標を $\bar{D}^{s}$, 同時期の一般区間の状態指標を $\bar{D}_{-}^{s}$, 選択区間の状態指標を $\bar{D}_{+}^{s}$ とする.

この $\bar{D}_{-}^{s}, \bar{D}_{+}^{s}$ は, 保全計画の策定方法によって当然 影響を受ける. 一般区間と選択区間の区分は, いわば全 体の区間から保全をより必要とする区間を選択する行為 とみることができる. したがって, 理想的には状態が悪 い箇所を選択区間に指定するものと考えられるが，一般 には保全は状態を考慮しない非状態保全（これは, 多く の場合, 定期保全となる.）と状態保全の混合とみなす

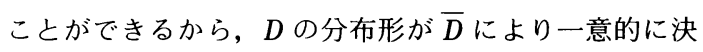
定することを考え合わせると, 選択区間における初期の 状態指標 $\bar{D}_{+}^{s}$ は, 全体の状態指標 $\bar{D}^{s}$ と選択保全率 $m-$ $N+1$ の関数として,

$$
\bar{D}_{+}^{s}=H\left[\bar{D}^{s}, m-N+1\right]
$$

として, 表わすことができると考えられる.この関数 $H$ を選択状態関数とよぶこととする (図一2参照). こ の定義に伴って, 一般区間の初期状態指標 $\bar{D}_{-}^{s}$ は, 式 $(2)$ を用いて,

$$
\bar{D}_{-}^{s}=\left\{\bar{D}^{s}-(m-N+1) \cdot H\left[\bar{D}^{s}, m-N+1\right]\right\} /(N-m)
$$

と表わされる.

注 3）対象区間は, 理論上は $0, \cdots, N$ 回保全の $N+1$ 種の 区間に区分され得るが, 期間 $\Delta T$ を 1 年とした場合でも, 実際 の保全回数 $N$ は在来線の場合, 輸送量の多い線区でたかだか 2 ～3 回程度であることや，5. ( 1 ）a）で述べるように対象区間を 設定する場合, 区間内では軌道狂い進み等に著しく大きな差異 はないことから, 事実上は本文のように 2 区分で十分である.

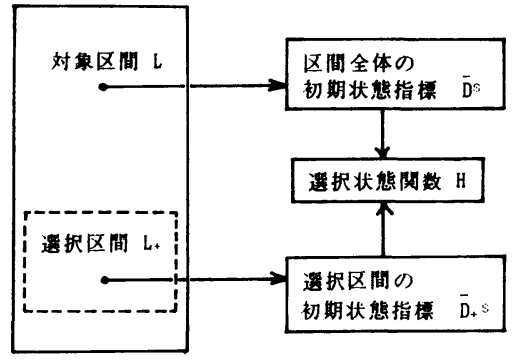

図一2 選択状態関数

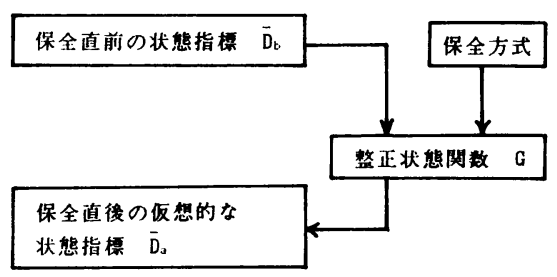

図一3 整正状態関数

次に機械作業, 人力作業などの複数の保全方式が混在 しているときを考える.この場合, 対象区間の中では, 方式別の対象区間があらかじめ定められているものとす ると社4，方式によって連続施工に対する適合性等に相 違があるため, 選択状態関数 $H$ にも方式により差異が あるものと考えられる. そこで, 保全方式 $j$ に選択状 態関数 $H_{j}$ が対応するものとする.

\section{（3）保全による整正特性}

保全の実施により状態指標は改善される，このとき従 来の研究によれば, 高低狂い整正の場合, 線路状態は保 全直後の比較的短期間の間に初期沈下に相当して悪化す ることが知られている11).そこでここでは, 保全を実施 する区間の保全直前の状態指標 $\bar{D}_{b}$ と, 保全直後の状態 から初期沈下相当分を控除した仮想的な状態指標 $\bar{D}_{a}$ に 着目する.この両者の関係は, 機械種別などの保全方式 の違いにより異なるものと考えられるが, 方式 $j$ につ いて次のような関数関係が成立するものとする(図一3). $\bar{D}_{a}=G_{j}\left[\bar{D}_{b}\right] \cdots$

本研究では, 関数 $G$ J 整正状態関数とよぶ. なお, 後 に述べる理由から関数 $G_{j}$ は, $\bar{D}_{b}$ について線形性が成 立するものとする. また, 選択状態関数と整正状態関数 とをあわせて, 本研究では保全特性関数とよぶ.

\section{（4）状態推移の定式的表現}

a) 状態指標の劣化特性

線路状態の劣化特性を表わすものとしては, 軌道狂い 進み $s$ がある.これは, 単位時間当たりの軌道狂いの

注 4) 機械作業の実施が困難な, 分岐器, 伸縮継目, 踏切な ごの区間は特別の場合を除きタイタンパーを用いた人手による 作業が行われる. 
最大值 $D$ の変化量として定義される. あるロットに着 目したときこの軌道狂い進み $s$ は短期的には一定の值 をとり，また線路構造，荷重環境などの外部条件が同一 の区間内ではほぼ指数分布に従って確率的に分布するこ とが明らかにされている121. したがって，指数分布の性 質からその平均值 $\bar{s}$ が定まれば，劣化特性はその分布 を含めて一意的に定まることとなる。このような特性に より本研究では, 劣化特性を代表する指標として対象区 間内における平均軌道狂い進み $\bar{s}$ を用いることとする. なお，対象とする区間内の任意の部分集合についても軌 道狂い進みの確率分布は同一であるとする．この場合， 任意のロットにおける期間 $\Delta t$ 経過後の最大值 $D$ は, 初期最大值 $D^{s}$ と軌道狂い進み $s$ により

$D=D^{s}+s \cdot \Delta t$

と表わされる.したがって, 対象区間全体の状態指標の 平均 $\bar{D}$ は劣化特性値として $\bar{s}$ を用いて，

$\bar{D}=\bar{D}^{s}+\bar{s} \cdot \Delta t$

とすることができる.

b）状態指標の推移

i ）一般区間の状態推移

いま, 保全率 $m$ が式 $(1)$ を満たすとすると, 一般 区間では $N-1$ 回の保全が行われる. 第 1 回目の保全の 時期は，一般区間の中でも一定ではないと考えられ，そ の時期に応じて複数に区分される.ここで, 時期 $T_{s}$ か ら保全実施時期までの期間を保全期間とよび，保全期間 $\Delta t_{-i}^{1}$ に対応する延長を $L_{-i}$ (ただし， $\left.\sum_{i} L_{-i}=L_{-}\right)$とす る. 保全期間が $\Delta t_{-i}^{1}$ の䇢所の保全後の状態指標 $\vec{D}_{-\imath}^{1}$ は, $\bar{D}_{-i}^{1}=G\left[\bar{D}_{-}^{s}+\bar{s} \cdot \Delta t_{-i}^{1}\right]$

となる。第 1 回目保全期間の平均を $\Delta \bar{t}_{-}^{1}(=\Sigma$ $\left.\Delta t_{-i}^{1} \cdot L_{-i} / L_{-}\right)$とすると, 保全期間が $\Delta t_{-i}^{1}$ の区間の $T_{S}$ $+\Delta \bar{t}_{-}^{1}$ の時期における状態指標 $\bar{D}_{-i}^{1 *}$ は,

$\bar{D}_{-i}^{1 *}=\bar{D}_{-i}^{1}-\bar{s} \cdot\left(\Delta t_{-i}^{1}-\Delta \bar{t}_{-}^{1}\right)$

と表わされる. したがって，一般区間全体での時期 $T_{s}$ $+\Delta \bar{t}_{-}^{1}$ における状態指標 $\bar{D}_{-}^{1}$ は, 整正状態関数 $G$ の線 形性の仮定により，

$$
\bar{D}_{-}^{1}=\sum_{i} \bar{D}_{-i}^{1 *} \cdot L_{-i} / L_{-}=G\left[\bar{D}_{-}^{s}+\bar{s} \cdot \Delta \bar{t}_{-}^{1}\right] \cdots
$$

と表わされる，同様にして，第 $k$ 回保全期間の平均を $\Delta \bar{t}_{-}^{k}$ として, その時点での状態指標 $\bar{D}_{-}^{k}$ は, 第 $k-1$ 回 の平均保全期間 $\Delta \bar{t}_{-}^{k-1}$ における状態指標 $\bar{D}_{-}^{k-1}$ を用い て,

$$
\bar{D}_{-}^{k}=G\left[\bar{D}_{-}^{k-1}+\bar{s} \cdot\left(\Delta \bar{t}_{-}^{k}-\Delta \bar{t}_{-}^{k-1}\right)\right]
$$

となる.この漸化式により $\bar{D}_{-}^{k} を k=N-1$ まで繰り返 し算出することにより, 第 $N-1$ 回の平均保全期間 $\Delta \bar{t}_{-}^{N-1}$ における状態指標 $\bar{D}_{-}^{N-1}$ が求められるから, 一般 区間の終期 $T_{E}$ における状態指標 $\bar{D}_{-}^{E}$ は,

$$
\bar{D}_{-}^{E}=\bar{D}_{-}^{N-1}+\bar{s} \cdot\left(\Delta T-\Delta \bar{t}_{-}^{N-1}\right) \cdot \cdots
$$

となる。こうして式（4)，(10)，(12）より一般区間に
おける状態指標の推移が記述されることになる.なお, 期間 $\Delta T$ の中で保全が初期から終期まで理想的に平均 化されて実施されておれば，第 $k$ 回目の平均保全期間 は,

$$
\Delta \bar{t}_{-}^{k}=(\Delta T /(N-1)) \cdot k \quad(\text { ただし }, N \geqq 2)
$$

と置くことができるので, 式 (10) (12) を簡略化する ことが可能である.

\section{ii）選択区間における状態推移}

選択区間についても同様にして, 状態指標の推移を記 述する諸式を導くことができるが，それらは単に式 (10) ～(12) の添え字一を十に置き換えたものにすぎないた め省略する，ただし，式（11）に相当する式の逐次計算 回数が $N$ 回になるのはいうまでもない. また，保全期 間が理想的に平均化されている場合の第 $k$ 回目の平均 保全期間は,

$$
\Delta \bar{t}_{+}^{k}=(\Delta T / N) \cdot k
$$

となる.

\section{iii）全区間の状態推移}

以上により一般区間と選択区間との終期状態指標 $\bar{D}_{-}^{E}, \bar{D}_{+}^{E}$ が求められれば，全体の終期状態指標 $\bar{D}^{E}$ は,

$$
\bar{D}^{E}=(N-m) \cdot \bar{D}_{-}^{E}+(m-N+1) \cdot \bar{D}_{+}^{E}
$$

として算出することができる.

c) 複数の保全方式が混在する場合

3. (2)に述べたとおり, 複数の保全方式が混在する 場合でも短期的には保全方式別の保全対象区間があらか じめ定められているとしているので, 保全方式別に状態 指標の推移式を構成することが可能で, 保全方式 $j$ の 別にb)により，終期値 $\bar{D}_{j}^{E}$ を算出し，保全方式別の保 全延長 $l$, を用いて, 全体の終期値 $\bar{D}^{E}$ を

$$
\bar{D}^{E}=\left(\sum l_{j} \cdot \bar{D}_{j}^{E}\right) / l \text {. }
$$

により算出することができる.

以上のように線路状態を表わす状態指標に平均最大值 をとり, 選択状態関数と整正状態関数とからなる保全特 性関数と平均軌道狂い進みを用いた劣化特性値を基本と して，その推移を定式的に表現することができるが，本 研究ではこのモデルを劣化・保全モデルとよぶこととす る.

\section{（５）状態指標の管理水準}

上述の劣化・保全モデルにより，外部環境としての劣 化特性值と初期状態指標とが与えられているとき，ある 保全延長の場合の終期状態指標が予測できることになる から，逆に終期状態指標をある目標值に設定したときの 所要保全延長を推定することが可能である.この場合, 状態指標の目標値としていかなる值を設定すべきかとい う問題が生じる.

線路状態の管理は, 乗心地維持と安全性確保の $2 \supset$ つ レベルが考えられるが，この両者は完全に独立したもの 
（A）マルティプルタイタンパーによる機械保全の埸合

(1) ランク 1

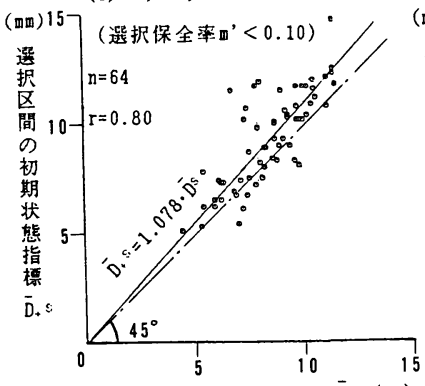

、全体の初期状热指標 $\bar{D}$ （m田）
(2) ランク 4

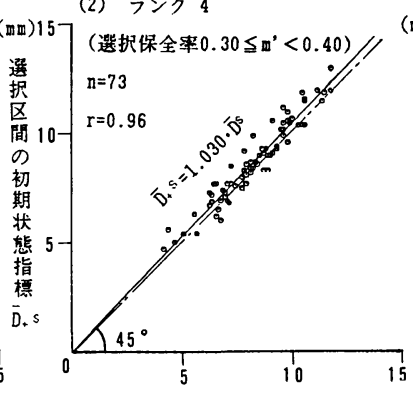

全体の初期状態指標 $\bar{D}$ s（m的）

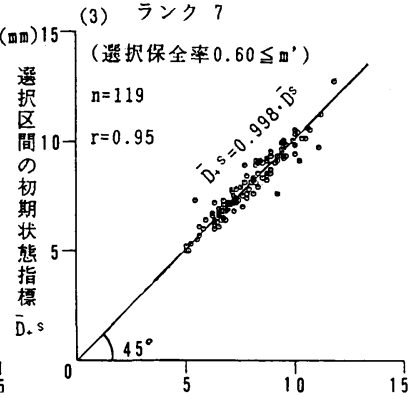

全体の初期状態指標 $\bar{D}$ s （mm）

（B）タイタンバーによる人力保全の堨合

(1) ランク 1.

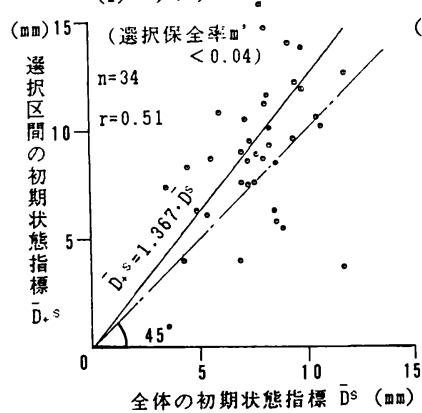

(2) ランク 6

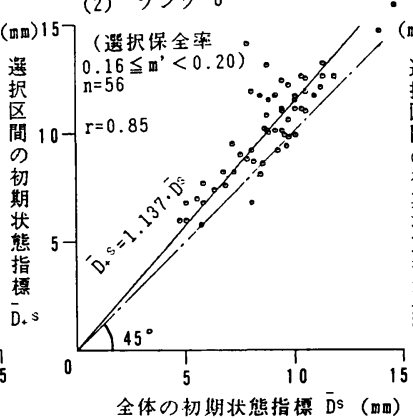

(3) ランク 9

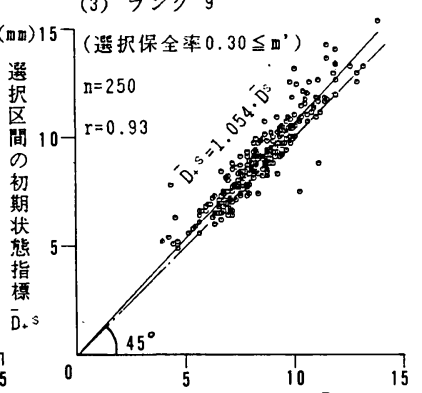

全体の初期状热指標 $\bar{D}$ s (mm)

図一4区間全体と選択区間の初期状態指槚の関係

ではなく，低位のレベルである乗心地維持を第一義的に 管理しておけば，高位の安全性確保は突発的に発生する 著大な軌道狂いを必要に応じて補修することにより通常 は満足させることができる性質のものである.

本研究で状態指標によった平均最大值は, その確率分 布も考虑すればミクロな状態の表示にも適用可能である とはいうものの, 基本的には対象区間全体のマクロな状 態を表わしているものと理解できる. 乗心地の立場から みた管理水準に関する研究は，個々の軌道狂い波形の波 長, 波高に関するミクロな視点に立ったもの ${ }^{3 / 4)}$ と， $P$ 值のようなマクロな指標に関するもの ${ }^{5)}$ とがある. 文献 5 ）は, 相当延長の区間における乗心地レベルを一定水 準に維持するために要求される， $P$ 值の管理水準を列 車を構成する車両形式や走行速度に応じて設定する方法 を提案したものである.さらに，P值が実用的な範囲 で軌道狂いの分散亡明示的な関係があり，また軌道狂い の分散と平均最大値 $\bar{D}$ との関係も経験的に求められて いること ${ }^{10)}$ から，線区に応じて乗心地からみた状態指標 の管理水準を設定することが可能となる.

\section{4. 保全特性関数の推定}

劣化・保全モデルを実際に適用するには，モデルの中 で重要な役割を担う, 選択状態関数と整正状態関数の 2
つの関数（保全特性関数）をあらかじめ推定しておく必 要がある．そこで，以下に述べるように国鉄全国在来線 の軌道狂いの定期的計測データを解析し, 保全特性関数 を推定した.

\section{（1）選択状態関数}

\section{a) 解析対象デー夕}

高低狂いの補修は, 現在のところマルティプル・タイ タンパーによる機械保全とタイタンパーによる人力保全 とに大別されるが，大型機械である前者では当然のこと ながら連続的な施工が経済的である。このように保全の 連続的施工によるメリットが保全方式によって異なる場 合には，選択状態関数も異なったものとなると考えられ る. そこで, 選択状態関数の推定にあたっては，まずこ の保全方式の別に昭和 56 年度の国鉄の全国の軌道計測 デー夕から, 各対象区間全体の初期状態指標 $\bar{D}^{s}$ 之選択 区間とされた区間の初期状態指標 $\bar{D}_{+}^{s}$ とを摘出して解析 した.

なお，ここで対象区間は全国の各線区を路線別，およ びまとまった線路保守の最小単位である保線支区別き5) に区分した区間のうち，特に延長が短い区間を除外した 598 か所の区間である.

注 5）国鉄全国の線路および構造物は約 170 の保線区，さら にその配下の約 250 の保線支区により保全されている. 
表一1 選択保全率と $\overline{\boldsymbol{D}}_{+}^{s} / \overline{\boldsymbol{D}}^{s}$ の解析結果

\begin{tabular}{|c|c|c|c|c|c|c|}
\hline 保全 & ランク & $\begin{array}{l}\text { 選全热 } \\
\end{array}$ & $\vec{r}-$ 夕数 & 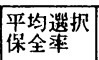 & 回沿係数 & 相閔係数 \\
\hline \multirow[t]{2}{*}{ 譏 } & 1 & $\sim 0.10$ & 64 & 0.056 & 1.078 & 0.80 \\
\hline & 2 & 0.10 & 106 & 0.151 & 1.047 & 0.90 \\
\hline \multirow[t]{2}{*}{ 械 } & 3 & 0.20 & 107 & 0.246 & 1.044 & 0.89 \\
\hline & 4 & $\begin{array}{l}0.30 \\
\sim 0.40\end{array}$ & 73 & 0.352 & 1.030 & 0.96 \\
\hline \multirow[t]{2}{*}{ 保 } & 5 & $\begin{array}{l}0.40 \\
\sim 0.50\end{array}$ & 57 & 0.447 & 1.038 & 0.97 \\
\hline & 6 & $\begin{array}{l}0.50 \\
\sim 0.60\end{array}$ & 39 & 0.547 & 1.003 & 0.93 \\
\hline \multirow[t]{2}{*}{ 全 } & 7 & $0.60 \sim$ & 119 & 0.840 & 0.998 & 0.95 \\
\hline & 1 & $\sim 0.04$ & 34 & 0.021 & 1.367 & 0.51 \\
\hline \multirow[t]{2}{*}{ 人 } & 2 & $\stackrel{0.04}{\sim 0.07}$ & 41 & 0.056 & 1.162 & 0.81 \\
\hline & 3 & 0.07 & 49 & 0.085 & 1.217 & 0.79 \\
\hline \multirow[t]{2}{*}{ 力 } & 4 & $\begin{array}{l}0.10 \\
\sim 0.13\end{array}$ & 36 & 0.115 & 1.274 & 0.83 \\
\hline & 5 & 0.13 & 32 & 0.144 & 1.154 & 0.89 \\
\hline \multirow[t]{2}{*}{ 保 } & 6 & 0.16 & 56 & 0.182 & 1.137 & 0.85 \\
\hline & 7 & $\begin{array}{l}0.20 \\
\sim 0.25\end{array}$ & 52 & 0.224 & 1.132 & 0.92 \\
\hline \multirow[t]{2}{*}{ 全 } & 8 & $\begin{array}{l}0.25 \\
20.30\end{array}$ & 42 & 0.270 & 1.108 & 0.90 \\
\hline & & $0.30 \sim$ & 250 & 0.585 & 1.054 & 0.93 \\
\hline
\end{tabular}

b) 解析結果

解析にあたっては, まず選択保全率 $m-N+1$ をいく つかのランクに区分し,それぞれのランク別に解析した. 図一4は，全体の初期状態指標 $\bar{D}^{s}$ と選択区間の初期状 態指標 $\bar{D}_{+}^{s}$ との関係を選択保全率のランク別に示したも のの一部である．表一1は，調査結果に原点回帰直線を あてはめた結果をとりまとめたものである.なお，ここ で原点直線回帰式を用いたのは考察でも述べるように, 理想的な状態保全が行われた場合との比較を行ううえで 都合がよいためである.

一部のデータ数の少ないランクを除き, 安定した回帰 分析結果となっている. この結果に基づいて, 保全方式 別に各ランクにおける回帰係数（すなわち, 平均的な $\bar{D}_{+}^{s} / \bar{D}^{s}$ の値) を各ランクの平均選択保全率に対してプ ロットした結果が図一5である，選択保全率が増大する に従って, $\bar{D}_{+}^{s} / \bar{D}^{s}$ の値は 1 に漸近すると考えられるこ とから，選択保全率を $m^{\prime}(=m-N+1)$ として, $\bar{D}_{+}^{s} / \bar{D}^{s}=1+c \cdot m{ }^{\prime a}(c, a:$ 定数, ただし, $a<0)$ の形 式の曲線をあてはめた結果を図一 5 中に併せ実線で示し た.この結果から, 選択状態関数は,

$$
\bar{D}_{+}^{s}=H\left[\bar{D}^{s}, m^{\prime}\right]=\left(1+c \cdot m^{a}\right) \cdot \bar{D}^{s}
$$

ここで,

$c=6.07 \times 10^{-3}, a=-1.11:$ 機械保全の場合 $c=4.14 \times 10^{-2}, a=-6.92 \times 10^{-1}:$ 人力保全の場合

と表わすことができる.

（2）整正状態関数

a) 解析対象データ

整正状態関数は, 保全実施前後の状態指標 $\bar{D}_{b}, \bar{D}_{a}$ の
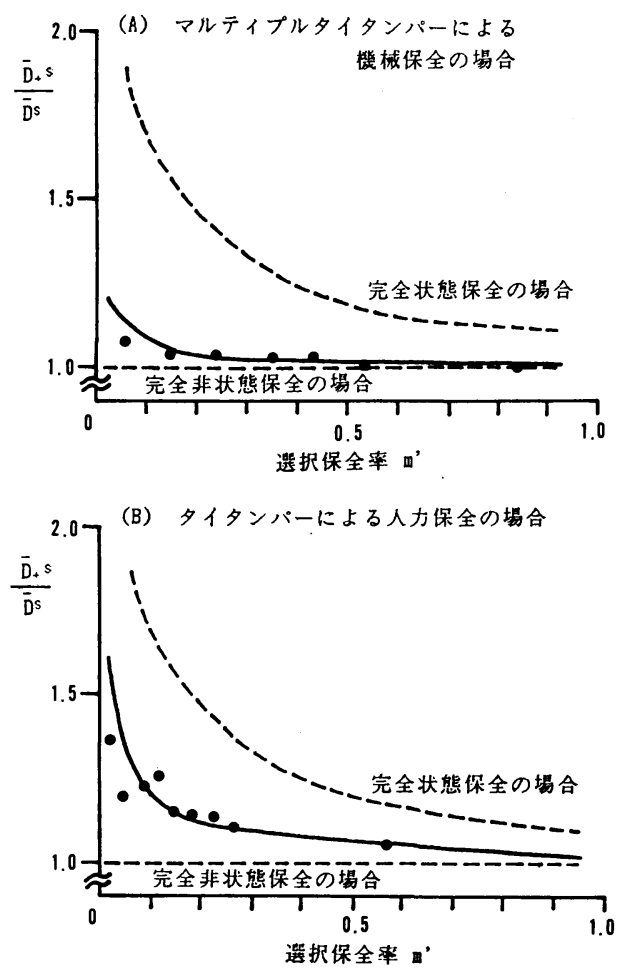

図一5 選択保全率と $\bar{D}_{+}^{s} / \bar{D}^{s}$

相互関係を示すものであるが，軌道検測車による軌道狂 いの計測周期は在来線の場合, 短い場合でも 2 か月程度 であるため，直接的には $\bar{D}_{b} や \bar{D}_{a}$ を知ることはできな い.そこで, 当該区間の平均軌道狂い進み $\bar{S}$ を昭和 55 〜 56 年度の 2 年間の計測データを用いて別途算出して おき, 次の式により推定して解析することとした（図一 1参照).

$$
\begin{aligned}
& \bar{D}_{b}=\bar{D}_{i n s b}+\bar{s} \cdot \Delta t_{i n s b} \\
& \bar{D}_{a}=\bar{D}_{i n s a}-\bar{s} \cdot \Delta t_{i n s a}
\end{aligned}
$$

ここで,

\section{$\bar{D}_{\text {insb }}$ ：保全前計測時の状態指標 \\ $\bar{D}_{\text {tnsa }}$ : 保全後計測時の状態指標}

$\Delta t_{\text {insb }}$ : 保全前計測時から保全実施までの期間

$\Delta t_{\text {insa }}$ : 保全実施から保全後計測時までの期間

また, 保全方式としては, 機械保全と人力保全の別に 加えて, 機械保全については, マルティプル・タイタン パーの機種により 6 種に分類して解析した。解析に用い たデータは, 選択状態関数の推定に用いたものと同様で ある。

b) 解析結果

図一はは,これらの結果の一部を図示したものである. 図をみてわかるとおり, 保全前後の状態指標は比較的単 純な関係にあるとみられ，また $\bar{D}_{b}=0$ のときには $\bar{D}_{a}=$ 
（A）マルティプルタイタンパーによる機械保全の場合
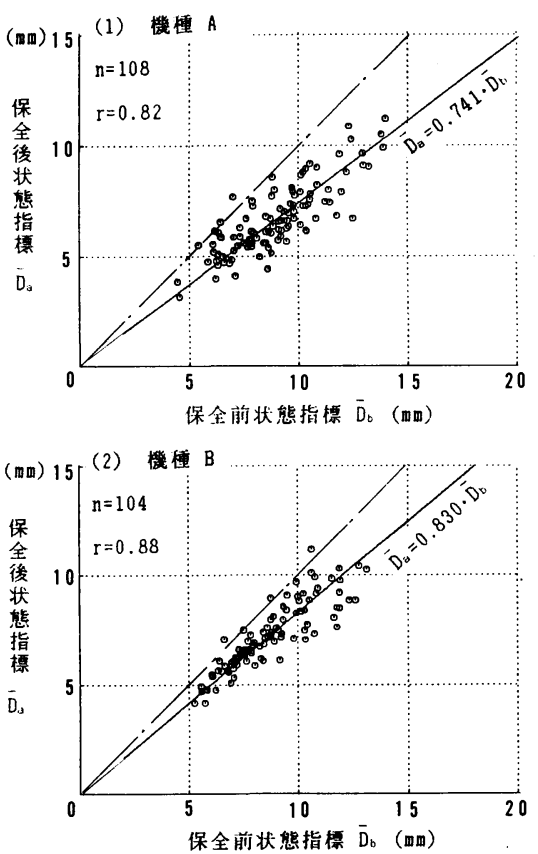

図一6 保全前後の状態指標

0 であるという経験的性質を考慮して原点回帰直線をあ てはめて推定した結果を併せて示した。この結果，保全 方式 $j$ の場合の回帰係数を $g_{j}$ とすれば, 整正状態関数 は,

$$
\bar{D}_{a}=G_{j}\left[\bar{D}_{b}\right]=g_{j} \cdot \bar{D}_{b}
$$

と表わされる.

\section{5. 劣化・保全モデルの適用と検証}

\section{（1）適用対象データとモデルの適用法}

前節では, 劣化・保全モデルの重要なサブモデルであ る保全特性関数の実データからの推定を試みた。本節で はこれらを用いて, 劣化・保全モデルを国鉄在来線の多 数の線区に適用し，状態指標推移の予測適合性を検証す る.

\section{a) 対象区間の選定}

モデルを適用する対象区間としては，路線別・保線支 区別の線区を単位として，次のような考え方により総数 222 か所を抽出した.

(1) 区間長が極端に短い区間は，デー夕解析上の安定 性に欠けるため，延長が $10 \mathrm{~km}$ 以上の区間を対象 とした.

(2) 対象とする期間内（昭和 56 年度）に軌道に大幅 な改良（たとえば, レールの重量化, コンクリート まくらぎ化）が加えられていたり，輸送量や列車速

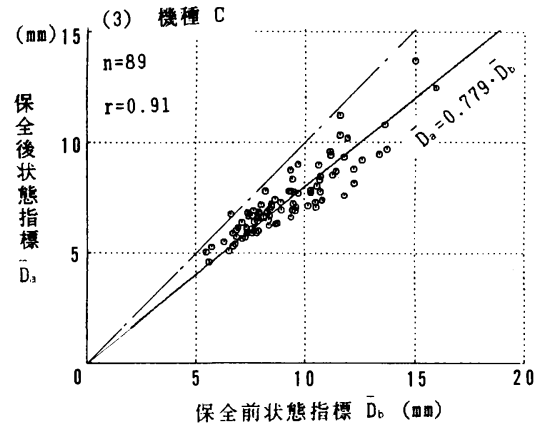

（B）タイタンパーによる人力保全の堨合

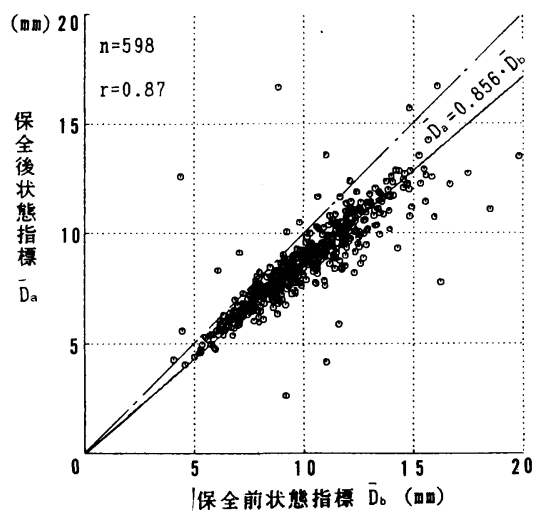

度の大幅な増減によって，期間内に軌道の劣化特性 が変化したと考えられる区間は対象から除外する。

(3) 対象とした各区間の中では, 軌道構造や輸送条件 に場所的な大きな違いがないとみなされること.

b）劣化特性值の算定

劣化・保全モデルの適用にあたっては，各対象区間の 劣化特性值として, 平均軌道狂い進みが必要である. そ こで本研究では整正状態関数の推定のときと同様に各区 間について，昭和 $55 \sim 56$ 年度の 2 年間の軌道計測デー 夕を用いて，20 mロットごとの軌道狂い進みを計算し， さらにそれらの区間内における平均をとり $\bar{s}$ を求めた.

c）モデルの適用法

対象亡する期間は, 昭和 56 年度年初から昭和 57 年度 年初の 1 年間をとり, 昭和 56 年度年初の軌道状態, 昭 和 56 年度の保全方式別保全延長実績を用いて, 昭和 57 年度年初の軌道状態を予測し，実績値との適合性を検討 することとした。

なお，保全実施時期については，昭和 56 年度の各月 の保全実績を別途調査した結果，いずれの対象区間とも おおむね年間を通じて平均化された保全を実施している ことが確認されたため，ここでは式 (13)，(14）により， 保全時期が完全に平準化されているものとしてモデルを 適用した。

また，劣化・保全モデルは，状態指標に軌道狂いの平 
均最大值をとっているが，現状の軌道保守システムでは 必ずしも全線にわたる平均最大值が集計されていないた め, より一般的に多用される $P$ 值から, 次の経験的関 係式により, 平均最大值を推定して適用し, 終期の状態 指標予測値も逆に $P$ 値に変換して実績值と比較するこ ととした.

$$
P=105.8 \cdot \log _{10} \bar{D}-60.1
$$

$P: P$ 値 $(\%), \bar{D}: 20 \mathrm{~m}$ ロットの平均最大值 $(\mathrm{mm})$

\section{（2）モデルの適用結果}

図一7は，上記の方法により対象 222 区間についての 昭和 57 年度年初の予測 $P$ 值と実現値とを比較したもの である，必ずしも適合していない箇所もみられるが，両 者の間の相関係数でみると 0.92 と高く, 全般的にみて 予測値は実績值におおむねよく適合し，劣化・保全モデ ルによる軌道状態予測が可能であると考えられる.

\section{6. 考察}

\section{（1）選択状態関数と状態保全率}

保全には，大別して状態指標の観測結果に基づいて指 標の高い䇢所の保全を実施する状態保全之，状態指標に かかわらずに保全を実施する（たとえば，定期保全）非 状態保全とがある．理想的に状態保全を実施するには状 態指標が高い数值となった箇所から予定された保全延長 に達するまで順次保全箇所を決定すればよい，軌道狂い の管理は前述のように列車の走行安全や乗客の乗心地を 確保するためのものであるから，状態保全に重きが置か れると考えるのが普通である．しかし，実際には施工箇 所が散在するのは保全の経済性からみて好ましくないた め，施工連続性の重視から必ずしも指標が大きな值でな い箇所についても保全を実施するという側面がある.

ここではまず，完全な状態保全または非状態保全が行 われた場合の選択状態関数を求め, 推定された選択状態 関数と比較することにより実際の保全の基本的性質を検 討することとする.

\section{a）完全状態保全の選択状態関数}

文献 10）によれば， $20 \mathrm{~m}$ ロット最大值 $D$ の累積分布 関数 $\Phi(D)$ は, 軌道狂いの標準偏差を $\sigma$ として,

$$
\Phi(D)=\exp [-\exp \{-1.31 \cdot(D / \sigma-2.29)\}] \cdots
$$

と表わされ, また式中の標準偏差 $\sigma$ は, 平均最大値 $\bar{D}$ と

$$
\sigma=0.372 \cdot \bar{D}^{1.04}
$$

という関係にあることが経験的に明らかにされている. また，選択保全率を $m$ 'としたとき，選択区間が状態指 標の高い箇所から理想的に順次指定されたとすると，そ の状態指標 $\bar{D}_{+}^{s}$ は近似的に,

$$
\Phi\left(\bar{D}_{+}^{s}\right) \fallingdotseq 1-m^{\prime} / 2 \cdot
$$

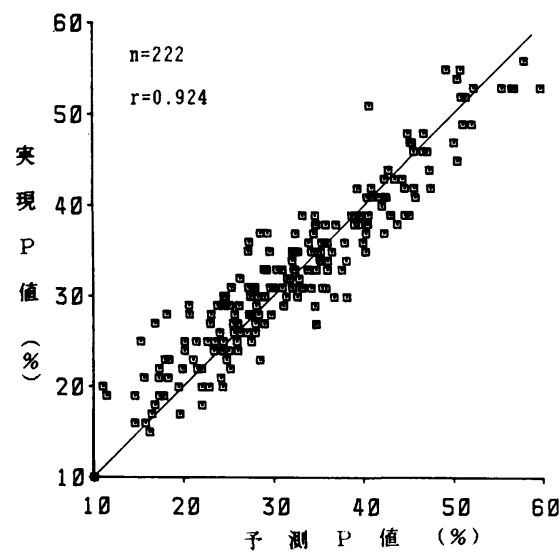

図一7劣化・保全モデルの適用結果

とおくことができる.したがって，式 (21)〜 (23) より, $\bar{D}^{s 1.04} \fallingdotseq \bar{D}^{s}$ 之近似すれば,

$\bar{D}_{+}^{s} / \bar{D}^{s} \fallingdotseq 0.852-0.284 \cdot \ln \left(\ln \left(1-m^{\prime} / 2\right)^{-1}\right)$ が得られる。

b）完全非状態保全の選択状態関数

この場合には，選択区間は状態指標とは全く独立して 選択されることになるから，全体に対して偏りのない部 分集合とみなすことができるため，

$$
\bar{D}_{+}^{s} / \bar{D}^{s}=1
$$

となる．以上により求められた式（24），(25）を図一5 中に点線で示した.

c) 状態保全率の推定

図一5でわかるとおり，現実の選択状態関数は，完全 状態保全の場合の選択状態関数と完全非状態保全の場合 の選択状態関数に挟まれており，この両者を適当な比率 で加算したものとみることができる．そこで, 完全状態 保全の重みを $r_{C M}$ (状態保全率), 完全非状態保全の重 みを $1-r_{C M}$ として, 表一1 の推定データについて最小 二乗法により $r_{C M}$ を推定した結果,

$r_{C M}=\left\{\begin{array}{l}0.092: \text { 機械保全の場合 } \\ 0.289: \text { 人力保全の場合 }\end{array}\right.$

となった，連続施工の経済効果の高い機械保全の場合に 状態保全率が低く，機動性の高い人力施工で高くなって いるのがわかる，経済性を考慮したうえでは，状態保全 率 $r_{C M}$ をごの程度の值にとるのが適切なのかは今後の研 究に待たねばならないが, 状態指標管理という意味から は状態保全率 $r_{C M}$ が高い方が効率的であることを考える と，改善する可能性があると考えられる.

\section{（2）整正状態関数の推定結果について}

整正状態関数は，図一6のように比較的単純なもの之 なり，全般的にみると保全直後の仮想的な状態指標は， 保全直前の状態指標の約 $0.75 \sim 0.85$ 倍となることが明 らかとなった、マルティプル・タイタンパーによる機械 
保全については一部を除き機種間に大きな差異は認めら れないが, タイタンパーによる人力保全の場合にはバラ ツキも大きく, また整正効果もやや低いことが目につく.

マルティプル・タイタンパーによる高低狂いの整備方 法には, 相対基準方式と絶対基準方式注6) とがあるが, 前者については整正前の軌道狂い波形と整正後の波形の 関係を数学的に表わすことが可能である. この場合, 理 論的には波長が $10 \mathrm{~m} \sim 30 \mathrm{~m}$ 程度の領域で軌道狂いの波 高は, $0.3 \sim 0.4$ 倍に低下させることができる ${ }^{13)}$.

これらの数值に比べ, 本研究で実証的に推定された結 果では, 整正効果が非常に低くなっているが，これは前 述のとおり，図一1に示すように保全直後には $\bar{D}_{b}$ から $\bar{D}_{M}$ にまで改善された状態指標が比較的短期間のうちに 初期沈下により悪化するが, 理論的な整正効果がいわば $\bar{D}_{b}$ と $\bar{D}_{M}$ の関係を示すのに対して, 推定された整正状 態関数はこの初期沈下相当分を控除した仮想的な状態 $\bar{D}_{a}$ を対象としているため, 整正効果が低く推定された ものと考えられる.

しかし，いずれにしてもこれら両者の違いは予想以上 で，初期沈下に相当する軌道狂いが大きいことを示して いる. 初期沈下は, 保全後かく乱された道床砕石が再び 安定するまでの過程と考えることができるが, 本研究で 明らかにしたように保全効果のかなりの部分が初期沈下 によって減殺されているとすれば, 保全の経済性からみ ても重大な問題点であるといえる.この点は今後の保全 の効率化を図って行くうえでは改善上 1 つのキーポイン トであると考えられる。

\section{（3）劣化・保全モデルの適用性}

本研究で構築した劣化・保全モデルは, 実務的な対象 区間単位で比較的短期的な状態指標予測や所要保全量推

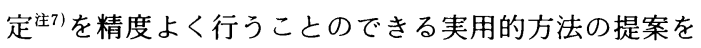
目的亡したものである. 5. で行ったモデルの適用性の 検討は, 対象期間を 1 年間にとった限られた条件下にお ける検証ではあるが, 実用上の要請が一般的には年度単 位の予測であること, および本研究で適用性検討に用い たデータが全国を対象とした幅の広いものであることか ら, その妥当性は確認されたものと考えられる. 現在, 国鉄では定期的な軌道狂いの計測業務の一環として各線 区の軌道狂い進みが計算・出力できるように計算機シス

注 6）相対基準方式による高低狂いの整正は，マルティプル タイタンパーのメカニカルな㗢きにより自動的に線路面の不整 を整正する方法で, 軌道狂いの波長により整正できる程度はお のずから定まる. 絶対基準方式は, あらかじめ測量等によって 得られた軌道面不整の状況から計画者が人為的に扛上量を決定 し整正するもので, 作業の手数はかかるが整正効果は大きい.

注 7) 所要保全量の推定は, 劣化特性値, 初期状態指標, 保 全特性関数を既知として，終期状態指標が目標値に合致するよ うに保全率を求めればよい. 一般に解析的には解けないが, 数 回の繰り返し計算により簡単に求めることができる.
テムが構築されつつあるが，この中に本研究で提案した 劣化・保全モデルを取り込むことも容易であると考えら れる.

\section{7. 結論および今後の課題}

本研究で得られた結論は以下のとおりである.

（1）状態指標に平均最大値, 劣化特性に平均軌道狂 い進みをとり，2つの保全特性関数を用いて状態推移を 定式的に表現した劣化・保全モデルを提案し，国鉄全国 のデータにより検証した結果，実用的にみて十分適合性 が認められた。

（2）保全特性関数の 1 万, 保全の基本的性質（状態 保全と非状態保全の実状）を示す，選択状態関数を新た に提案し，実データによりこれを推定したが，この結果 から現状の保全が非状態保全に偏りがちで，経済的な意 味で基本的な問題点があり得ることを明らかにした。

（3）同じく保全特性関数のうち, 整正状態関数につ いては，その基本的特性を明らかにしたが，理論的整正 効果から考えると初期沈下に相当する効果が予測以上に 大きく，保全特性を向上するうえでは初期沈下抑制策が 有効であると考えられることが示された。

また，今後の課題としては，結論中に述べた保全特性 関数の性状改善に関する実証的研究が保全経済上重要で あるが，その他に次のような点が挙げられる.

（1）本研究で用いた実測デー夕は, 昭和 56 年度の もので, 昭和 50 年代から今日までの軌道状態の推移過 程の中ではほぼ代表的な状態といえるものである. 今後 は，軌道状態がより悪化した状態や相当に改善された状 態についても保全特性関数の推定などを行っていくこと が重要である.

（2）本研究では基本的前提として, 短期的には劣化 特性値すなわち軌道狂い進みが状態指標には独立してい るものとして扱ったが，今後はこの前提をより一般的な ものに緩和した状況下におけるモデル構築を図っていく ことが必要である.

\section{8. あとがき}

本研究を実施するにあたっては，東海旅客鉄道 杉山 徳平氏, 東日本旅客鉄道 小山内政広氏には, 研究の推進, 理論的検討などで多大なるご協力を得た。また，東京大 学工学部 松本嘉司教授には, 拙稿をお読み頂いたうえ, 種々のご指導をいただいた．ここに深く感謝する次第で ある.

\section{参 考 文 献}

1）星野陽一・佐藤 裕：軌道構造の動力学的設計, 鉄道技 術研究報告 No. 149, 国鉄鉄道技術研究所, 1960 .

2）佐藤吉彦：新軌道破壊理論の構成, 鉄道技術研究所速報, 
No.77-47, 国鉄鉄道技術研究所, 1975.

3）佐藤吉彦：乗心地の立場から見た軌道高低狂いの整備限 度, 鉄道技術研究報告 No. 549, 国鉄鉄道技術研究所, 1966 .

4）池守昌幸：軌道狂いの波形の整備に関する研究, 鉄道技 術研究報告 No. 1038, 国鉄鉄道技術研究所, 1977 .

5) 家田 仁. 小林専慈 - 岸本 隆 : 列車の乗心地と軌道狂 (状態管理水準に関する検討 (上, 下), 鉄道線路 32 巻 4 号, pp. $174 \sim 178,5$ 号, pp. $218 \sim 222$, 日本鉄道施設 協会, 1984 .

6）小野木次郎：鉄道軌道の変位の研究, 鉄道技術研究報告 No. 1081, 国鉄鉄道技術研究所, 1978 .

7）杉山徳平：軌道狂い進みの実態調査とその解析, 鉄道技 術研究報告 No. 1081, 国鉄鉄道技術研究所, 1978 .

8）杉山徳平. 吉見一彦・宮井徹 - 細川岳洋 : 保線 6 支区 における軌道破壊量と軌道保守量の実態調查, 鉄道技術
研究所速報 No. 79-120, 国鉄鉄道技術研究所, 1975 .

9）池守昌幸：軌道狂い状態の経時変化モデルとその応用, 土木学会論文集, No. 365／IV-4, pp. 145 154, 1986.

10）佐藤吉彦・細川岳洋：高速軌道検測記録（マヤチャート） の $10 \mathrm{~m}$ 代表値と $20 \mathrm{~m}$ 代表值の統計的特性に関する検討, 鉄道技術研究所速報 No. 82-75, 国鉄鉄道技術研究所, 1982.

11）佐藤 裕：軌道力学, 鉄道現業社, pp. 41 50, 1978 .

12）杉山徳平·家田 仁·上野昌喜・山口義信：軌道狂い状 態を考虑した軌道破壊の要因分析, 鉄道線路 34 巻 9 号, 日本鉄道施設協会, pp. 8 12, 1986.

13）山口義信・家田 仁：マルタイは軌道狂いをどう直すか, 新線路第 40 巻 9 号, 鉄道現業社, pp. 12 14, 1986.

(1986.12.3 • 受付) 